\title{
Amyotrophic Lateral Sclerosis with IgM Antibody against Gangliosides GM2 and GD2
}

\author{
Kotaro Mizutani, Nobuyuki OKA*, Susumu KusunOKI**, Ryuji KaJI***, \\ Masutaro KANDA****, Ichiro AKIGUCHI and Hiroshi SHIBASAKI
}

\begin{abstract}
We report a case of amyotrophic lateral sclerosis (ALS) with IgM antibody against gangliosides GM2 and GD2. A 57-year-old woman presented with slowly progressive muscular weakness of the upper extremities and dysarthria. She fulfilled the clinical and electrophysiological criteria of ALS, and died from sudden suffocation about 3 years after the onset of illness. The patient's serum IgM antibody was shown to recognize the structure shared by GM2 and GD2. Since anti-GM2 antibodies have been implicated in motor neuropathy or motor neuron syndrome, this rare case might contribute to the understanding of the immunological aspects of ALS. (Internal Medicine 42: 277-280, 2003)
\end{abstract}

Key words: anti-GM2 antibodies, antiganglioside antibodies, motor neuron disease

\section{Introduction}

Amyotrophic lateral sclerosis (ALS) is a fatal neurodegenerative disorder characterized by loss of motor neurons in the central nervous system. The etiology of sporadic ALS remains unclear, although abnormalities of the $\mathrm{Cu} / \mathrm{Zn}$ superoxide dismutase gene have been detected in some familial cases $(1,2)$. Several reports have shown that immunoinflammatory processes are involved in the pathology of ALS (3-5). In addition, a variety of immunological abnormalities have been reported in some patients with ALS (69). Gangliosides (sialic acid-containing glycosphingolipids) are abundant in the nervous system, and serum antiganglio- side antibodies are occasionally detected in some immunemediated neurological disorders (10-13). We encountered a sporadic ALS patient with serum IgM antibody against gangliosides GM2 and GD2.

For editorial comment, see p 220.

\section{Case Report}

\section{Patient}

The patient was a 57-year-old woman who was hospitalized with a 5-month history of slowly progressive muscular weakness of the upper extremities and dysarthria. On examination, weakness was prominent in the right forearm and small hand muscles (2-3/5 on the Medical Research Council scale), but lower extremity strength was preserved. Muscular atrophy was noted in the right and left thenars. Deep tendon reflexes were exaggerated in the extremities with bilateral Babinski sign. Fasciculations were observed in the tongue. There were no sensory deficits. She had no skin lesions suggesting malignant melanoma, which is occasionally associated with chronic inflammatory demyelinating polyneuropathy and IgM anti-GM2 antibodies (14).

The level of fasting blood sugar was within the normal range. Thyroid function was normal. M-protein was not detected by serum immunoelectrophoresis. Hepatitis B surface antigen was positive with mild liver dysfunction. IgM anticytomegalovirus antibody was negative. The antibody test for human T-lymphotropic virus type I (HTLV-I) was negative, which ruled out the possibility of a pseudo-ALS form of HTLV-I-associated myelopathy (15). Examination of cerebrospinal fluid revealed a cell count of $1 / \mu l$ and protein level of $36 \mathrm{mg} / \mathrm{dl}$. Motor nerve conduction studies showed mark-

From the Department of Neurology, Kyoto University Graduate School of Medicine, Kyoto, *the Division of Neurology, Department of Internal Medicine, Hyogo College of Medicine, Nishinomiya, **the Department of Neurology, Graduate School of Medicine, University of Tokyo, Tokyo, ***the Department of Clinical Neuroscience, Tokushima University Hospital, Tokushima and ****the Division of Neurology, Takeda General Hospital, Kyoto

Received for publication May 16, 2002; Accepted for publication November 25, 2002

Reprint requests should be addressed to Dr. Nobuyuki Oka, the Division of Neurology, Department of Internal Medicine, Hyogo College of Medicine, 1-1 Mukogawa-cho, Nishinomiya 663-8501 


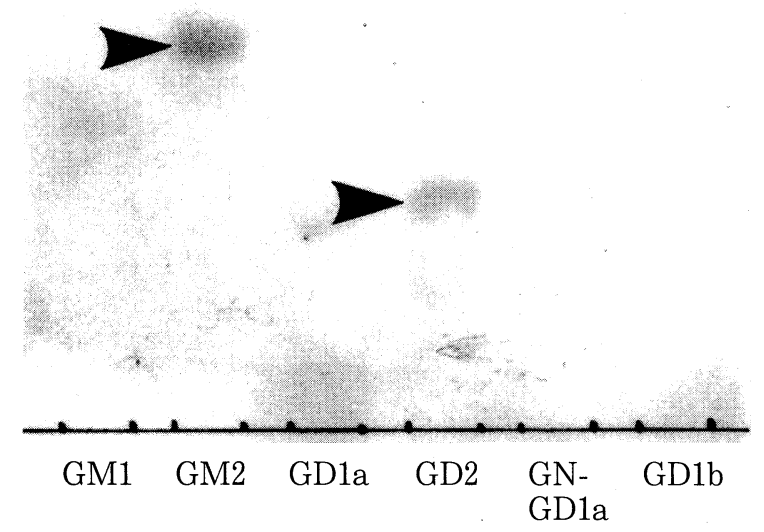

Figure 1. TLC-immunostaining with IgM in the patient's serum, diluted 1:80. The binding activity of the IgM antibody of the patient's serum to GM2 and GD2 is demonstrated (arrowheads). GN-GD1a: GalNAc-GD1a.

edly reduced compound muscle action potential amplitudes in the left median and the right median and ulnar nerves without slowed conduction velocity or conduction block. Needle electrode examination revealed evidence of active denervation in all extremities (first dorsal interosseous, extensor digitorum communis, and gastrocnemius muscles).

The patient did not respond to high-dose intravenous immunoglobulin treatment, which was administered considering the possibility of a treatable neuroimmunological disorder $(13,16,17)$. She was clinically and electrophysiologically diagnosed as having ALS. After discharge, she developed dysphagia and muscular weakness of the lower extremities, and then became wheelchair bound. She died from sudden suffocation about 3 years after the onset of illness.

\section{Methods}

Serum antiganglioside antibodies (IgM and $\mathrm{IgG})$ were in- vestigated by enzyme-linked immunosorbent assay (ELISA) as described previously (12). Tested ganglioside antigens were GM1, GM2, GM3, GD1a, GD1b, GD3, GT1b, and GQ1b obtained from Funakoshi (Tokyo, Japan) and $\mathrm{N}$ acetylgalactosaminyl GD1a (GalNAc-GD1a) obtained as described previously (12). Antibody titer was expressed as the maximal dilution factor which gave a corrected optical density of more than 0.1 (normal, less than 1:40). The results of ELISA were confirmed using thin-layer chromatogram (TLC)-immunostaining performed as described previously (12). ELISA using peroxidase-conjugated rabbit anti-human kappa or lambda light chain antibodies (DAKO, Glostrup, Denmark) as second antibodies was also performed to assess polyclonality or monoclonality of the patient's serum antibody.

The absorption test was performed as follows. Each well of a 96-well microtiter plate was coated with $0.4 \mu \mathrm{g}$ of each ganglioside. The wells were filled with $1 \%$ bovine serum albumin in phosphate-buffered saline for 30 minutes and emptied. The plate was incubated with the patient's serum diluted 1:200 for 2 hours at room temperature then left overnight at $4^{\circ} \mathrm{C}$. After absorption, the antiganglioside antibody titer of each sample was measured by ELISA.

\section{Results}

The patient's serum IgM was reactive with GM2 (antibody titer of 1:640), but not with GM1, GM3, GD1a, GD1b, GD3, GalNAc-GD1a, GT1b, or GQ1b (less than 1:40). The binding activity of the antibody to GM2 was detected with both anti-human kappa and lambda light chain antibodies as second antibodies, suggesting that the antibody was polyclonal (data not shown). There were no IgG antibodies against any of the antigens tested. The anti-GM2 antibody titer remained high throughout the course of the illness. Since the IgM anti-GM2 antibody of the patient was not cross-reactive with GM1 or GalNAc-GD1a, cross-reactivity with GD2 was additionally examined. The patient's serum IgM was also reactive with GD2 (1:320). Reactivities with GM2 and GD2 were confirmed by TLC-immunostaining (Fig. 1). Absorption with GM2 or GD2, but not with GM1 or GalNAc-GD1a, reduced the antibody activities (Table 1). Thirty other patients with ALS were also tested for serum anti-GM2 and anti-GD2 antibodies (IgM and $\operatorname{IgG}$ ), and the

Table 1. Absorption Test

\begin{tabular}{lcc}
\hline & IgM anti-GM2 antibody & IgM anti-GD2 antibody \\
\hline Not absorbed & 0.464 & 0.21 \\
Absorbed with GM2 & $<0.1$ & $<0.1$ \\
Absorbed with GM1 & 0.385 & 0.259 \\
Absorbed with GalNAc-GD1a & 0.366 & 0.218 \\
Absorbed with GD2 & $<0.1$ & $<0.1$ \\
\hline
\end{tabular}

Absorption of the patient's serum was performed with $0.4 \mu \mathrm{g}$ of each ganglioside. Data are optical density values. 
results were all negative (data not shown). In addition, we present previous cases with IgM anti-GM2 antibodies in our laboratory: one patient with multifocal motor neuropathy (antibody titer of 1:2,560) (13) and five with Guillain-Barré syndrome (GBS) subsequent to cytomegalovirus infection (1:40 to $1: 640)$.

\section{Discussion}

Cavanna et al (18) measured IgM anti-GM2 antibodies in the sera of 224 patients with different neuropathies and motor neuron disease (MND), and found high titers of the antibodies in eight patients with dysimmune neuropathies. All of those patients had a concomitant IgM reactivity with either GM1 or GalNAc-GD1a, the latter sharing the terminal trisaccharide with GM2 (Fig. 2). However, the present patient's serum IgM was not reactive with GM1 or GalNAcGD1a, but with GD2. The absorption test revealed that the IgM antibody mainly recognizes the moiety shared by GM2 and GD2 (Fig. 2). Similar reactivities with GM2 and GD2 have been observed in the serum antiganglioside antibodies of patients with GBS subsequent to cytomegalovirus infection $(19,20)$. Yuki et al $(21)$ measured IgM and IgG antiGD2 antibodies in the sera of 257 patients with various neurological disorders, and found high titers of the antibodies in seven patients including five with GBS. One of these GBS patients had IgM antibody against GD2, GM2, and GalNAc-GD1a.

GM2 may be an immunologically unique ganglioside. Tai et al (22) reported that GM2 appears to be the most immunogenic among gangliosides found on human melanoma cells. We recently reported that GM2 markedly enhances the production of tumor necrosis factor- $\alpha$ in peripheral blood mononuclear cell culture (23). In addition, GM2 is thought to be a possible major component of motor neuron gangliosides $(24,25)$.

Antibodies against several kinds of gangliosides other than GM2 have been detected in MND (26-28). O'Hanlon et al (29) recently reported three MND patients with IgM antiGM2 antibodies whose cross-reactivity with GD2 was not described. Interestingly, high-titer IgM antibody against GM2 was detected in a patient who developed an ALS-like disorder after intramuscular treatment with bovine brain gangliosides for diabetic neuropathy (30). The IgM antiGM2 antibody in that patient was cross-reactive with GalNAc-GD1a (31), but not with GD2 (30). In addition, Nakao et al (32) found two novel GM2-epitope containing gangliosides in bovine brain with that patient's serum IgM. Similarly, there might be unknown gangliosides in the central nervous system that react with our patient's serum IgM.

As one of the autoimmune hypotheses in ALS, autoreactive antibodies might be taken up at the nerve ending and transported within the axons (33). It was reported that immunoglobulins from ALS patients enhance spontaneous transmitter release from motor nerve terminals (7). IgM monoclonal antibody against terminal moiety of GM2 and
GM2

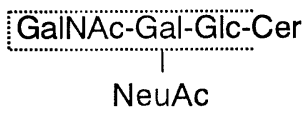

GalNAc-GD1a

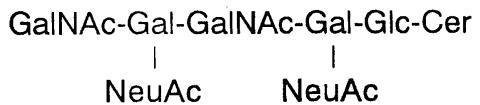

GM1

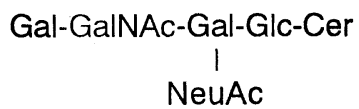

GD2

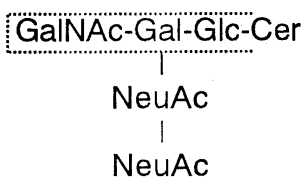

Figure 2. Structures of gangliosides GM2, GalNAcGD1a, GM1 and GD2. GalNAc: $N$-acetylgalactosamine, Gal: galactose, Glc: glucose, Cer: ceramide, NeuAc: $N$ acetylneuraminic acid. GM2 and GD2 have a GalNAcGal-GIc-moiety in common (dotted line).

GalNAc-GD1a has recently been shown to have effects on neurotransmitter release (34). These pathophysiological mechanisms involving motor nerve terminals may account for selective damage to motor nerves or motor neurons. Although the pathogenic significance of IgM anti-GM2 antibodies in MND is still undetermined (29), the present rare case might contribute to the understanding of the immunological aspects of ALS.

This work was supported by grants-in-aid for peripheral neuropathy and neuroimmunological diseases from the Japanese Ministry of Health, Labour and Welfare, and a Grant-in-Aid for Scientific Research (C-11672402) from the Japanese Ministry of Education, Culture, Sports, Science and Technology.

\section{References}

1) Rosen DR, Siddique $T$, Patterson $D$, et al. Mutations in $\mathrm{Cu} / \mathrm{Zn}$ superoxide dismutase gene are associated with familial amyotrophic lateral sclerosis. Nature 362: 59-62, 1993 (published erratum appears in Nature 364: 362, 1993).

2) Radunovic A, Leigh PN. $\mathrm{Cu} / \mathrm{Zn}$ superoxide dismutase gene mutations in amyotrophic lateral sclerosis: correlation between genotype and clinical features. J Neurol Neurosurg Psychiatry 61: 565-572, 1996.

3) Engelhardt JI, Appel SH. IgG reactivity in the spinal cord and motor cortex in amyotrophic lateral sclerosis. Arch Neurol 47: 1210-1216, 1990.

4) Kawamata $T$, Akiyama H, Yamada $T$, McGeer PL. Immunologic reactions in amyotrophic lateral sclerosis brain and spinal cord tissue. Am J Pathol 140: 691-707, 1992.

5) Engelhardt JI, Tajti J, Appel SH. Lymphocytic infiltrates in the spinal cord in amyotrophic lateral sclerosis. Arch Neurol 50: 30-36, 1993.

6) Shy ME, Rowland LP, Smith T, et al. Motor neuron disease and plasma cell dyscrasia. Neurology 36: 1429-1436, 1986.

7) Uchitel OD, Appel SH, Crawford F, Sczcupak L. Immunoglobulins 
from amyotrophic lateral sclerosis patients enhance spontaneous transmitter release from motor-nerve terminals. Proc Natl Acad Sci USA 85: 7371-7374, 1988.

8) Smith RG, Hamilton S, Hofmann F, et al. Serum antibodies to L-type calcium channels in patients with amyotrophic lateral sclerosis. N Engl J Med 327: 1721-1728, 1992.

9) Okuyama Y, Mizuno T, Inoue H, Kimoto K. Amyotrophic lateral sclerosis with anti-acetylcholine receptor antibody. Intern Med 36: 312315, 1997.

10) Pestronk A, Cornblath DR, Ilyas AA, et al. A treatable multifocal motor neuropathy with antibodies to GM1 ganglioside. Ann Neurol 24: 73-78, 1988.

11) Chiba A, Kusunoki S, Shimizu T, Kanazawa I. Serum IgG antibody to ganglioside GQ1b is a possible marker of Miller Fisher syndrome. Ann Neurol 31: 677-679, 1992.

12) Kusunoki S, Chiba A, Kon K, et al. N-Acetylgalactosaminyl GD1a is a target molecule for serum antibody in Guillain-Barré syndrome. Ann Neurol 35: 570-576, 1994.

13) Kaji R, Kusunoki $S$, Mizutani $K$, et al. Chronic motor axonal neuropathy associated with antibodies monospecific for $\mathrm{N}$-acetylgalactosaminyl GD1a. Muscle Nerve 23: 702-706, 2000.

14) Weiss MD, Luciano CA, Semino-Mora C, Dalakas MC, Quarles RH. Molecular mimicry in chronic inflammatory demyelinating polyneuropathy and melanoma. Neurology 51: 1738-1741, 1998.

15) Vernant JC, Buisson G, Bellance R, Francois MA, Madkaud O, Zavaro O. Pseudo-amyotrophic lateral sclerosis, peripheral neuropathy and chronic polyradiculoneuritis in patients with HTLV-I-associated paraplegias. in: HTLV-I and the Nervous System. Roman GC, Vernant JC, Osame M, Eds. Alan R Liss, New York, 1989: 361-365.

16) Kaji R, Shibasaki H, Kimura J. Multifocal demyelinating motor neuropathy: cranial nerve involvement and immunoglobulin therapy. Neurology 42: 506-509, 1992.

17) van den Berg-Vos RM, Franssen H, Wokke JHJ, van Es HW, van den Berg LH. Multifocal motor neuropathy: diagnostic criteria that predict the response to immunoglobulin treatment. Ann Neurol 48: 919-926, 2000.

18) Cavanna B, Carpo M, Pedotti R, et al. Anti-GM2 IgM antibodies: clinical correlates and reactivity with a human neuroblastoma cell line. J Neuroimmunol 94: 157-164, 1999.

19) Irie $S$, Saito $T$, Nakamura $K$, et al. Association of anti-GM2 antibodies in Guillain-Barré syndrome with acute cytomegalovirus infection. J Neuroimmunol 68: 19-26, 1996.

20) Jacobs BC, van Doorn PA, Groeneveld JHM, Tio-Gillen AP, van der Meché FGA. Cytomegalovirus infections and anti-GM2 antibodies in Guillain-Barré syndrome. J Neurol Neurosurg Psychiatry 62: 641-643, 1997.

21) Yuki N, Yamada M, Tagawa Y, Takahashi H, Handa S. Pathogenesis of the neurotoxicity caused by anti-GD2 antibody therapy. J Neurol Sci 149: 127-130, 1997.

22) Tai $T$, Cahan LD, Tsuchida $T$, Saxton RE, Irie RF, Morton DL. Immunogenicity of melanoma-associated gangliosides in cancer patients. Int J Cancer 35: 607-612, 1985.

23) Mizutani K, Oka N, Akiguchi I, et al. Enhancement of TNF- $\alpha$ production by ganglioside GM2 in human mononuclear cell culture. Neuroreport 10: 703-706, 1999.

24) Yoshino H, Michikawa M, Uchihara T, et al. Gangliosides and sulfated glucuronyl glycolipids in isolated bovine spinal motoneurons. Muscle Nerve Suppl 1: S158, 1994 (Abstract).

25) Matsumoto A, Yoshino H, Yuki N, et al. Ganglioside characterization of a cell line displaying motor neuron-like phenotype: GM2 as a possible major ganglioside in motor neurons. J Neurol Sci 131: 111-118, 1995.

26) Pestronk A, Adams RN, Clawson L, et al. Serum antibodies to GM1 ganglioside in amyotrophic lateral sclerosis. Neurology 38: 14571461, 1988.

27) Pestronk A, Adams RN, Cornblath D, Kuncl RW, Drachman DB, Clawson L. Patterns of serum IgM antibodies to GM1 and GD1a gangliosides in amyotrophic lateral sclerosis. Ann Neurol 25: 98-102, 1989.

28) Nobile-Orazio E, Legname G, Daverio R, et al. Motor neuron disease in a patient with a monoclonal IgMk directed against GM1, GD1b, and high-molecular-weight neural-specific glycoproteins. Ann Neurol 28: 190-194, 1990.

29) O'Hanlon GM, Veitch J, Gallardo E, Illa I, Chancellor AM, Willison HJ. Peripheral neuropathy associated with anti-GM2 ganglioside antibodies: clinical and immunopathological studies. Autoimmunity 32: 133-144, 2000.

30) Yuki N, Sato S, Miyatake T, Sugiyama K, Katagiri T, Sasaki H. Motoneuron-disease-like disorder after ganglioside therapy [letter]. Lancet 337: 1109-1110, 1991.

31) Yuki N, Miyatake $T$, Ichihashi $Y$, Sato $S$, Katagiri T. IgM anti(GalNAc $\beta 1-4$ Gal[3-2 $\alpha$ NeuAc] $\beta 1-$ ) antibody-mediated cytotoxicity in a patient with amyotrophic lateral sclerosis-like disorder [letter]. Muscle Nerve 15: 1371-1373, 1992.

32) Nakao T, Kon $K$, Ando $S$, et al. Novel lacto-ganglio type gangliosides with GM2-epitope in bovine brain which react with $\operatorname{IgM}$ from a patient of the amyotrophic lateral sclerosis-like disorder. J Biol Chem 268: 21028-21034, 1993.

33) Drachman DB, Kuncl RW. Amyotrophic lateral sclerosis: an unconventional autoimmune disease? Ann Neurol 26: 269-274, 1989.

34) Ortiz N, Rosa R, Gallardo E, et al. IgM monoclonal antibody against terminal moiety of GM2, GalNAc-GD1a and GalNAc-GM1b from a pure motor chronic demyelinating polyneuropathy patient: effects on neurotransmitter release. J Neuroimmunol 119: 114-123, 2001. 